\title{
A new species of Canalisporium from Australia
}

\author{
Teik Khiang Goh ${ }^{1}$ \\ Kevin D. Hyde \\ Center for Research in Fungal Diversity, Department of \\ Ecology and Biodiversity, The University of Hong \\ Kong, Pokfulam Road, Hong Kong SAR, People's \\ Republic of China
}

\begin{abstract}
Canalisporium variabile sp. nov. is described and illustrated based on several specimens from submerged wood and decaying palm rachis in Australia. It is most similar to $C$. pallidum in having pale conidia with clearly visible septa and canals, but they are two distinct species. In C. pallidum, conidia are more stable in shape, size and septation, with mostly a single column of vertical septa. In C. variabile, however, conidia are more variable in morphology, with mostly two columns of vertical septa, and the cells are more constricted. Conidia of $C$. pallidum are generally longer and more slender than those of C. variabile, which are generally shorter and broader. Canalisporium variabile is also compared with $C$. pulchrum and C. kenyense.

Key Words: dematiaceous hyphomycetes, freshwater fungi, lignicolous fungi, mitosporic fungi, septal pores, systematics
\end{abstract}

In a continuing study of the fungi occurring on submerged wood in tropical streams (Hyde et al 1998, Lee et al 1998, Wong et al 1999) we collected a previously undescribed species of Canalisporium. Canalisporium Nawawi \& Kuthub. was introduced to accommodate species of Berkleasmium Zobel having complanate conidia with orderly arranged septa in rows and columns and with narrow canals in the septa connecting adjacent cell lumens (Goh et al 1998, Nawawi and Kuthubutheen 1989). The genus has recently been reviewed by Goh et al (1998) and currently comprises six species, namely $C$. caribense (Hol.-Jech. \& Mercado) Nawawi \& Kuthub., C. exiguum Goh \& K. D. Hyde, C. pulchrum (Hol.-Jech. \& Mercado) Nawawi \& Kuthub., C. elegans Nawawi \& Kuthub., C. kenyense Goh, W. H. Ho \& K. D. Hyde, and C. pallidum Goh, W. H. Ho \& K. D. Hyde.

Accepted for publication January 4, 2000.

'Email: tkgoh@hkucc.hku.hk
The new species superficially resembles $C$. pallidum in having pale conidia, but differs in the number and arrangement of conidial septa. It is therefore described in this paper as a new species, and compared with $C$. pallidum as well as with other species (TABLE I). A composite diagram illustrating conidia of all seven Canalisporium species is provided to facilitate comparison (see FIGS. 13-21).

Canalisporium variabile Goh et K.D. Hyde, sp. nov.

FIGS. 1-12, 19-21

Sporodochia in substrato naturali punctiformia, dispersa, atrogrisea, granulata et in humido nitida, hemisphaerica, 200-400 $\mu \mathrm{m}$ lata. Mycelium plerumque in substrato immersum, ex hyphis ramosis, septatis, subhyalinis, 2-3 $\mu \mathrm{m}$ latis, laevibus, compositum. Conidiophora micronemata vel semi-macronemata, mononemata, fasciculata, simplicia vel sparse ramosa, laevia, hyalina vel subhyalina, usque $20 \mu \mathrm{m}$ longa, 1.5-2 $\mu \mathrm{m}$ lata. Cellulae conidiogenae in conidiophoris incorporatae, terminales, determinatae, cylindricae vel leniter vesiculosae. Conidia 22-35 × 15-23 × 10-10.5 $\mu \mathrm{m}$, acrogena, solitaria, complanata, laevia, in conspectis superficialibus plus minusve ellipsoidea vel obovoidea, interdum subglobosa vel cubica vel subtriangularia, in conspectis lateralibus cylindrica vel late clavata, fere recta, pallide olivacea vel flavidobrunnea, muriformia, plerumque cum septis longitudinalibus biserialis vel raro uniserialis et $2-4(-5)$ septis transversis in ordinem, non vittatis, tenuis praedita, interdum cum 1-2 septis verticalis additis praedita, ad septa conspicue constricta, lumina cellularum canaliculis conspicue connexa, cellula basali cuneiformia, subhyalina, tenuitunicata, $2.5-5 \mu \mathrm{m}$ lata, conidiorum secessio rhexolytica.

Sporodochia on natural substratum punctiform, scattered, dark gray, granular, glistening when wet, hemispherical, 200-400 $\mu \mathrm{m}$ wide (FIGs. 1, 2). Mycelium mostly immersed in the substratum, composed of branched, septate, subhyaline to golden brown, 2$3 \mu \mathrm{m}$ wide, smooth hyphae. Conidiophores micronematous or semi-macronematous, mononematous, fasciculate, simple or sparsely branched, smooth, hyaline or subhyaline, up to $20 \mu \mathrm{m}$ long and 1.5-2 $\mu \mathrm{m}$ wide. Conidiogenous cells integrated, terminal, determinate, cylindrical, becoming vesiculate as conidia mature (FIG. 5). Conidial secession rhexolytic. Conidia 22-35 × 15-23 × 10-10.5 $\mu \mathrm{m}$, acrogenous, solitary, one-cell thick and flattened, smooth, variable in shape: in surface view more or less ellipsoidal or obovoid, sometimes subglobose or cubical to subtrian- 

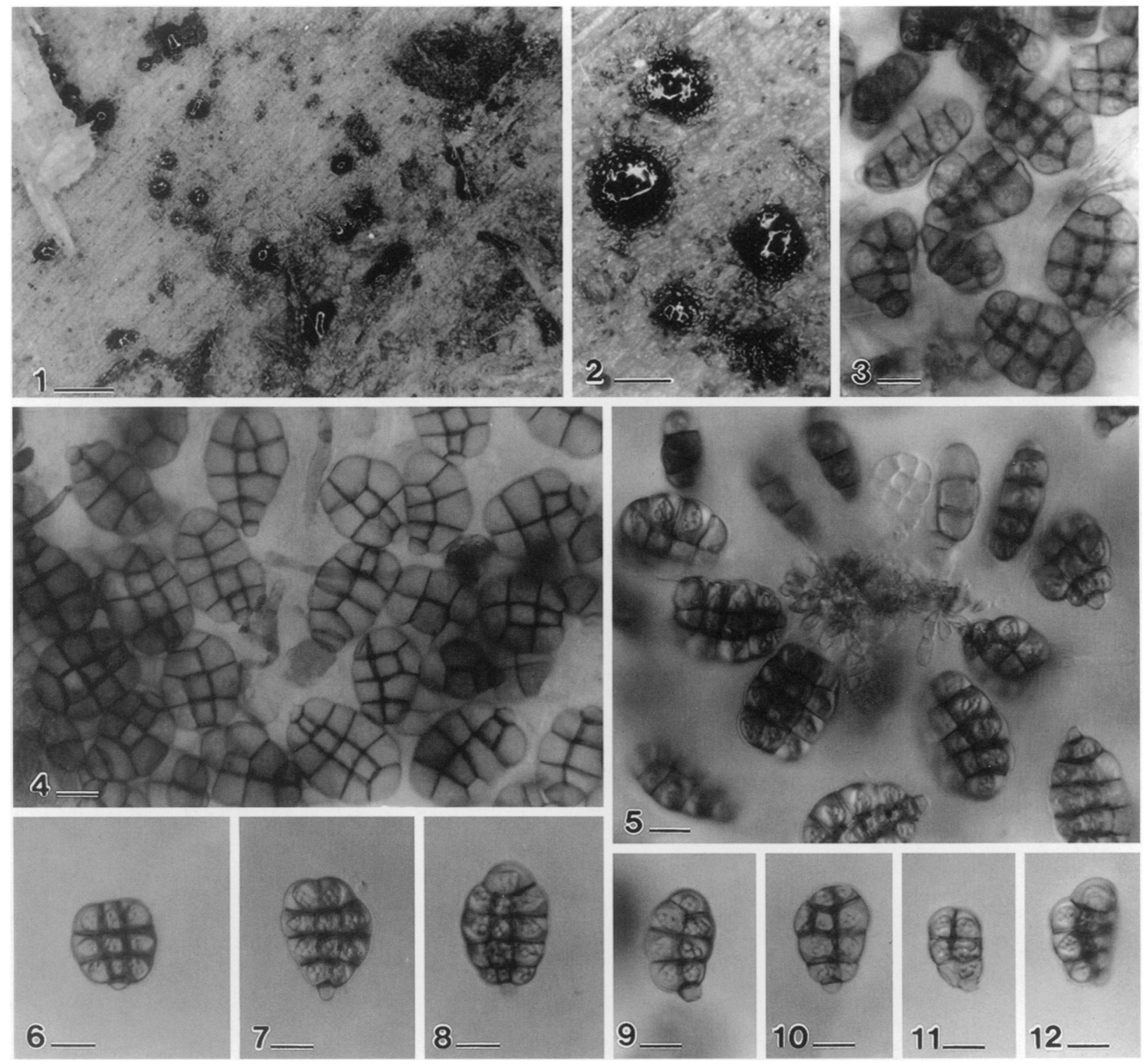

FIGs. 1-12. Canalisporium variabile, from HOLOTYPE (HKU(M) 7438). 1. Colony on submerged wood. 2. Close-up of wet sporodochia on natural substratum. Note the glistening conidial mass. 3. Conidia with septal canals in focus. 4. A mass of conidia with septa in focus. 5. Squash mount illustrating a mass of vesiculate conidiogenous hyphae with developing and mature conidia. $6-12$. Conidia illustrating a variation of shape, size, and septal arrangement. Bars: $1=500 \mu \mathrm{m}, 2=200$ $\mu \mathrm{m}, 3-12=10 \mu \mathrm{m}$.

gular; in lateral view cylindrical or broadly clavate and mostly straight, pale olivaceous to yellowish brown, muriform, usually moderately to strongly constricted at conidial septa and thus the cells appear to bulge in outline; septa unpigmented, thin and septal canals clearly visible, the majority with two columns of vertical septa and 2-4(-5) rows of transverse septa, some with a single column of septa and usually slightly curved, occasionally one or two of the central rows of cells may have additional 1-2 vertical septa, apex comprising a single cell or two to three cells, basal cell cuneiform, subhyaline, thin-walled, 2.5-5 $\mu \mathrm{m}$ wide (FIGs. 3-12, 19-21).

Known distribution. Australia.

Teleomorph. Unknown.

Specimens examined. AUSTRALIA. QUEENSLAND: Atherton Tablelands, Cowry Creek, on wood submerged in creek, 1 May 1998, K. D. Hyde, HOLOTYPE: HKU(M) 7438; ibid. HKU (M) 7441; ibid. HKU(M) 7442; ibid. on submerged decaying rachis of Oraniopsis appendiculata (Arecaceae), 1 May 1998, K. D. Hyde, HKU(M) 8243.

Etymology. Variabile, in reference to the conidia, which vary in shape and number and arrangement 

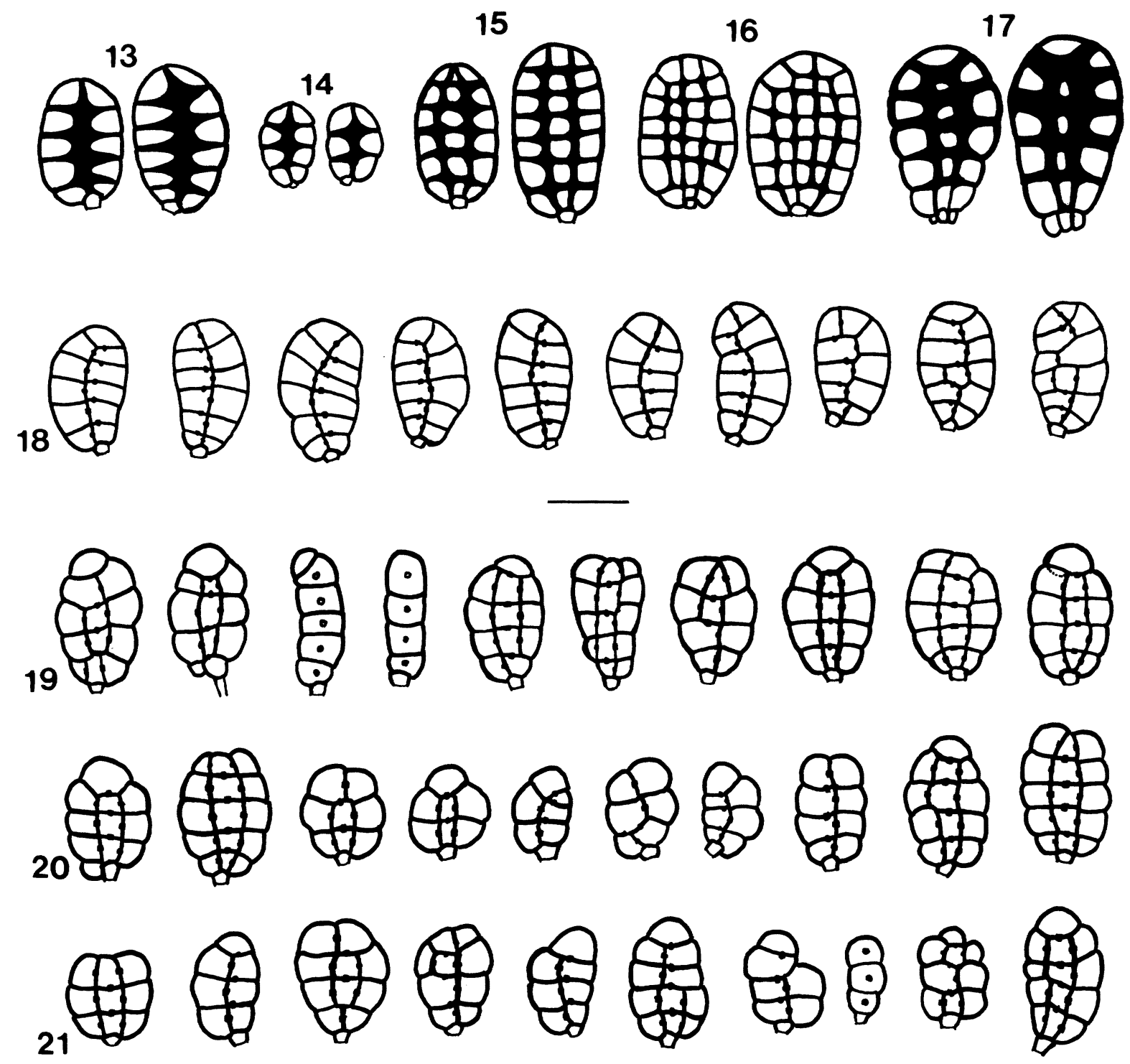

FIGs. 13-21. Conidia of Canalisporium spp. drawn to the same scale for comparison. 13. C. caribense. 14. C. exiguum. 15 . C. pulchrum. 16. C. elegans. 17. C. kenyense. 18. C. pallidum. 19-21. C. variabile. Bar $=20 \mu \mathrm{m}$.

TABLE I. Comparison of conidial morphology in Canalisporium species (Goh et al 1998)

\begin{tabular}{|c|c|c|c|c|c|c|c|c|c|}
\hline Species & Pigmentation & $\begin{array}{l}\text { Length } \\
(\mu \mathrm{m})\end{array}$ & $\begin{array}{l}\text { Width } \\
(\mu \mathrm{m})\end{array}$ & $\begin{array}{c}\text { Lateral } \\
\text { thickness } \\
(\mu \mathrm{m})\end{array}$ & $\begin{array}{l}\text { Accentuation } \\
\text { of septa }\end{array}$ & $\begin{array}{l}\text { Columns } \\
\text { of } \\
\text { vertical } \\
\text { septa }\end{array}$ & $\begin{array}{c}\text { Rows of } \\
\text { transverse } \\
\text { septa }\end{array}$ & $\begin{array}{l}\text { Cells } \\
\text { in } \\
\text { apical } \\
\text { row }\end{array}$ & $\begin{array}{l}\text { Basal } \\
\text { cells }\end{array}$ \\
\hline C. caribense & moderate to dark & $21-51$ & $15-29$ & $9-12.5$ & yes & 1 & $3-6$ & 2 & single \\
\hline C. exiguum & moderate to dark & $18-25$ & $13-15$ & $5-8$ & yes & 1 & $2-3(-4)$ & 2 & single \\
\hline C. pulchrum & moderate to dark & $25-63$ & $(16-) 20-32$ & $(10-) 12-17$ & yes & 2 & $3-9$ & $1-3$ & single \\
\hline C. elegans & moderate & $32-58$ & $25-38$ & $10-13$ & moderately & $(3-) 4-5$ & $5-8$ & $1-5$ & single \\
\hline C. kenyense & dark & $34-56$ & 24-34 & $14-18$ & yes & 2 & $(3-) 4-5(-7)$ & 1 & triple \\
\hline C. pallidum & pale & $25-39$ & $15-20(-22)$ & $8-10$ & no & mostly 1 & $4-5$ & $1-2$ & single \\
\hline C. variabile & pale & $22-35$ & $15-23$ & $10-10.5$ & no & mostly 2 & $2-4(-5)$ & $1-3$ & single \\
\hline
\end{tabular}


of septa, as compared to other known species which normally have characteristic shapes and particular arrangement of conidial septa.

Notes. The conidia in C. variabile are not heavily pigmented and the septal canals are clearly visible. Each vertical septum is perforated near its center by a canal. In the case of conidia having two columns of vertical septa (i.e., with three columns of cells), only the central column of cells have canals in the transverse septa (FIG. 19). In such conidia, all septal canals are central in position. Conidia having only a single column of vertical septa (i.e., with two columns of cells) are usually slightly curved. In those conidia, all the vertical septa possess a centrally positioned canal, but only the cells on the concave side of such conidia possess canals in their transverse septa and those on the convex side are not perforated (FIGS. 20, 21). The canals in the transverse septa of those conidia are not centrally situated, but assume a position very close to the corresponding vertical septa. This feature also occurs in conidia of C. pallidum (FIG. 18).

Canalisporium variabile can be distinguished from the other six species in the genus by comparing their conidial pigmentation and septation (see FIGS. 1321; TABLE I). It is however most similar to C. pallidum (see Goh et al 1998), which also has pale-colored conidia, with unaccentuated septa and therefore the septal canals are clearly visible. A few conidia in $C$. variabile having two columns of cells also resemble those of C. pallidum in having the canals in transverse septa being closer to the vertical septa. Despite these similarities, there are several features that distinguish C. variabile from $C$. pallidum. The major difference is that in $C$. variabile the majority of the conidia have two columns of vertical septa and 2-4 rows of transverse septa. In $C$. pallidum conidia predominately have a single column of vertical septa, but with 4-5 rows of transverse septa (FIG. 18), although occasion- ally in both species there are a few conidia with irregularly arranged septa. The conidia in $C$. variabile are however, more variable in shape due to the variation in conidial septation (FIGs. 19-21). They are relatively shorter and wider when compared with those of C. pallidum (which measure 25-39 $\times 15-20$ $\mu \mathrm{m})$. Moreover, in $C$. variabile the conidial cells are distinctly constricted and thus bulge in outline, whereas those in C. pallidum are more or less smooth in conidial contour.

The majority of conidia of $C$. variabile are also comparable to those of $C$. pulchrum (FIG. 15) and $C$. kenyense (FIG. 16), since they all possess two columns of vertical septa. In the latter two species, however, conidia are usually darker, with the septa heavily accentuated and thus the septal canals are often obscured. The conidia in these three species also differ in size and in other morphological characters. For comparison of conidial morphology in Canalisporium species, refer to TABLE I and Goh et al (1998).

Helen Leung and AYP Lee are thanked for their technical and photographic assistance.

\section{LITERATURE CITED}

Goh TK, Ho WH, Hyde KD, Whitton SR, Umali TE. 1998. New records and species of Canalisporium (Hyphomycetes), with a revision of the genus. Can J Bot 76:142152.

Hyde KD, Wong SW, Jones EBG. 1998. Diluviocola capensis gen. et sp. nov., a freshwater ascomycete with unique polar caps on the ascospores. Fung Divers 1:133-146.

Lee OHK, Goh TK, Hyde KD. 1998. Diplocladiella aquatica, a new hyphomycete from Brunei. Fung Divers 1:165168.

Nawawi A, Kuthubutheen AJ. 1989. Canalisporium, a new genus of lignicolous hyphomycetes from Malaysia. Mycotaxon 34:475-487.

Wong SW, Hyde KD, Jones EBG. 1999. Ultrastructural studies on freshwater ascomycetes. Fluminicola bipolaris gen. et sp. nov. Fung Divers 2:189-197. 